\title{
COVID-19 DAN UPAYA PENCEGAHAN PENYEBARAN DI RT 15 RW 03 KELURAHAN RAWA MAKMUR PERMAI KECAMATAN MUARA BANGKAHULU KOTA BENGKULU
}

\author{
Ahmad Soleh $^{1 *}$, Suwarni ${ }^{2)}$, Novia Triana Yasirudin ${ }^{3)}$ \\ ${ }^{1,2,3)}$ Fakultas Ekonomi, Universitas Dehasen Bengkulu \\ *Corresponding author: ahmadsolehse81@ yahoo.co.id
}

\begin{abstract}
ABSTRAK
Pandemi COVID-19 yang melanda di berbagai belahan dunia termasuk Indonesia, menuntut perhatian banyak pihak terkhusus dalam upaya penanganan dan pencegahan penyebarannya. Berbagai kebijakan dan program telah dilakukan oleh pemerintah terkait hal tersebut. Namun, perkembangan kasus virus corona yang belum menunjukkan penurunan baik secara nasional maupun di provinsi Bengkulu, menuntut peran aktif seluruh lapisan masyarakat maupun akademisi dalam upaya mencegah penyebarannya. Kegiatan pengabdian kepada masyarakat dilaksanakan di RT 15 RW 03 Kelurahan Rawa Makmur Permai Kecamatan Muara Bangkahulu Kota Bengkulu. Berbagai kegiatan yang dilakukan dalam upaya mencegah penyebaran virus corona adalah melalui kegiatan edukasi COVID-19, pemberian brosur dan pemberian masker. Melalui sosialisasi dan edukasi, warga lebih memahami terkait dari pemahaman konsep, tanda atau gejala inveksi virus, tindakan pencegahan yang dilakukan jika terdapat anggota keluarga yang menunjukkan gejala Virus Corona (COVID19). Melalui brosur yang diberikan dan dipasang di bagian rumah warga juga dianggap efektif dalam pemahaman dan aplikasi. Selanjutnya pemberian masker kain sangat bermanfaat dalam mengurangi potensi penularan virus corona.
\end{abstract}

\section{Kata Kunci: COVID-19, Edukasi, Pencegahan, Penyebaran}

\section{PENDAHULUAN}

Penyakit Coronavirus 19 (COVID-19) adalah infeksi virus yang sangat mudah menular dan disebabkan oleh sindrom pernafasan akut Coronavirus 2 (SARSCoV-2). Virus yang muncul di Wuhan, Cina dan menyebar ke seluruh dunia. Analisis genom mengungkapkan bahwa SARS-CoV-2 secara filogenetik terkait dengan virus kelelawar seperti sindrom pernapasan akut (seperti SARS) yang parah. Oleh karena itu kelelawar bisa menjadi reservoir primer yang mungkin. Sumber perantara asal dan transfer ke manusia tidak diketahui. Namun, cepat transfer manusia ke manusia telah dikonfirmasi secara luas (Shareen, et. al, 2020; Lupia, et. al, 2020).
COVID-19 yang dipicu pada Desember 2019 di kota Wuhan, yang berada di provinsi Hubei, Cina. Virus ini terus menyebar ke seluruh dunia. Di tengah risiko kesehatan masyarakat yang signifikan yang dimiliki COVID-19 bagi dunia, Organisasi Kesehatan Dunia (WHO) menyatakan darurat kesehatan publik yang menjadi perhatian internasional untuk mengkoordinasikan tanggapan internasional terhadap penyakit ini (Baldwin \& Mauro, 2020).

Penyebaran virus yang begitu cepat dan masif ke berbagai negara di dunia, menjadikan COVID-19 sebagai pandemi (Hidayaturrahman \& Purwanto, 2020). Dari waktu ke waktu jumlah korban yang terinfeksi cenderung meningkat, baik yang 


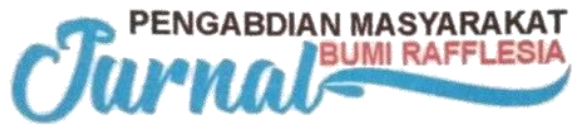

dinyatakan positif maupun tidak terduga, beberapa di antaranya juga telah dinyatakan sembuh (Rothan \& Bycldy, 2020). Hingga pada tanggal 9 Juli 2020, terdapat 12,1 juta kasus, 500 ribu meninggal dan pasien sembuh yang cenderung meningkat. Amerika Serikat dan Brazil merupakan negara dengan jumlah kasus COVID-19 tertinggi (https://mataram.tribunnews.com).

Indonesia merupakan salah satu negara yang juga terdampak pandemi COVID-19. Berdasar data yang dipublikasikan oleh Gugus Tugas Percepatan Penanganan COVID-19 menunjukkan bahwa perkembangan kasus COVID-19 di Indonesia cenderung mengalami peningkatan. Akumulasi data nasional per 9 Juli 2020 menunjukkan bahwa terdapat sejumlah 70.736 kasus terkonfirmasi. Data tersebut terdiri atas 34.668 dalam perawatan/isolasi mandiri, 32.651 sembuh dan 3.417 meninggal. Tanggal 9 Juli 2020 juga merupakan periode peningkatan kasus tertinggi jika dibanding dengan periode sebelumnya yakni mencapai 2.657 kasus (https://covid19.go.id/).

Bengkulu yang juga merupakan salah satu provinsi di Indonesia, tidak luput dari pandemi COVID-19. Per 9 Juli 2020, jumlah kasus terkonfirmasi sebanyak 141 kasus atau sebesar $0,2 \%$ jika dibanding data nasional. Hal tersebut menempatkan provinsi Bengkulu berada pada urutan ke 5 terbawah capaian kasus jika dibanding dengan provinsi lain di Indonesia (https://covid19.go.id/). Namun demikian, hal ini tetap menjadi perhatian serius pemerintah provinsi Bengkulu dalam menanggulangi kemungkinan terjadinya penyebaran yang lebih luas.

Atas jumlah kasus COVID-19 yang terkonfirmasi, tersebar di beberapa kabupaten dan kota Bengkulu. Kota Bengkulu terdiri atas sembilan kecamatan dan 67 kelurahan. Berdasar pengamatan yang dilakukan terutama di kota Bengkulu, kesadaran masyarakat akan bahaya COVID-19 dan upaya pencegahan masih relatif terbatas. Berdasar kondisi tersebut, kegiatan pengabdian kepada masyarakat dengan mengangkat tema COVID-19 dan upaya pencegahan penyebaran penting untuk dilakukan.

\section{METODE KEGIATAN}

Kegiatan Pengabdian kepada Masyarakat ini dilaksanakan di RT 15 RW 03 Kelurahan Rawa Makmur Permai Kecamatan Muara Bangkahulu Kota Bengkulu. Kegiatan ini dilaksanakan dari tanggal 15 sampai 20 Juni 2020.

Metode kegiatan dalam upaya pencegahan penyebaran COVID-19 dilakukan melalui:

a. Edukasi COVID-19

Edukasi COVID-19 kepada warga dimaksudkan untuk memberikan informasi secara langsung terkait bahaya COVID-19, mekanisme penularan dan penanganan.

b. Pemberian Brosur

Pemberian brosur dimaksudkan untuk lebih memudahkan dalam menyampaikan pesan kepada warga.

c. Pemberian Masker

Pemberian masker diharapkan dapat mengurangi penyebaran COVID-19.

\section{HASIL DAN PEMBAHASAN}

Pelaksanaan kegiatan Pengabdian kepada Masyarakat yang dilaksanakan di RT 15 RW 03 Kelurahan Rawa Makmur Permai Kecamatan Muara Bangkahulu Kota Bengkulu adalah sebagai berikut:

\section{A. Edukasi COVID-19}

Edukasi COVID-19 kepada warga dilakukan dengan mendatangi satu per satu rumah warga. Hal ini dilakukan seiring dengan himbauan pemerintah kepada semua warga untuk menghindari kegiatan pengumpulan massa selama masa pandemi COVID-19.

Kegiatan ini dilakukan dengan melakukan diskusi dengan warga. Hal ini dilakukan untuk menggali sejauh mana 
pemahaman warga terkait dengan COVID19. Beberapa hal yang disampaikan dan didiskusikan adalah:

\section{1) Apakah Anda mengetahui tentang Virus Corona (COVID-19)?}

Sebagian besar dan secara umum warga memahami virus corona (COVID-19) terutama berasal dari berita di media elektronik. Dalam hal ini kami melengkapi penjelasan virus corona mengacu pada pedoman pencegahan dan pengendalian coronavirus disease (COVID-19) bahwa coronavirus adalah keluarga besar virus yang menyebabkan penyakit mulai dari gejala ringan sampai berat. Ada setidaknya dua jenis coronavirus yang diketahui menyebabkan penyakit yang dapat menimbulkan gejala berat seperti Middle East Respiratory Syndrome (MERS) dan Severe Acute Respiratory Syndrome (SARS). Coronavirus Disease 2019 (COVID-19) adalah penyakit jenis baru yang belum pernah diidentifikasi sebelumnya pada manusia. Virus penyebab COVID-19 ini dinamakan Sars-CoV-2. Virus corona adalah zoonosis artinya ditularkan antara hewan dan manusia (Direktorat Jenderal Pencegahan dan Pengendalian Penyakit, 2020).

2) Apa saja tanda atau gejala infeksi Virus Corona (COVID-19)?

Pada pertanyaan ini, sebagian besar warga menjawab tanda atau gejala infeksi virus corona diawali dengan demam dan kesulitan bernafas. Selanjutnya kami juga menambahkan bahwa tanda dan gejala umum infeksi COVID-19 antara lain gejala gangguan pernapasan akut seperti demam, batuk dan sesak napas. Masa inkubasi ratarata 5-6 hari dengan masa inkubasi terpanjang 14 hari. Pada kasus COVID-19 yang berat dapat menyebabkan pneumonia, sindrom pernapasan akut, gagal ginjal, dan bahkan kematian. Tanda-tanda dan gejala klinis yang dilaporkan pada sebagian besar kasus adalah demam, dengan beberapa kasus mengalami kesulitan bernapas, dan hasil rontgen menunjukkan infiltrat pneumonia luas di kedua paru (Direktorat Jenderal Pencegahan dan Pengendalian Penyakit, 2020).

Dalam hal ini kami juga menyampaikan bahwa jika terdapat warga dengan gelaja tersebut dan pernah melakukan perjalanan ke daerah Zona Merah, hendaknya orang tersebut melakukan pemeriksaan laboratorium lebih lanjut untuk memastikan diagnosisnya.

3) Bagaimana pengobatan infeksi Virus Corona (COVID-19)?

Beberapa warga menjawab penanganan virus corona dengan melakukan isolasi mandiri dan perawatan di rumah sakit. Dalam hal ini kami juga menyampaikan bahwasannya saat ini belum ada pengobatan khusus yang efektif untuk infeksi virus corona. Sementara ini, cara terbaik adalah melakukan tindakan pencegahan yang paling efektif di masyarakat yaitu:

$\checkmark$ Sering mencuci tangan menggunakan sabun dan air mengalir atau dapat menggunakan hand sanitizer jika tangan tidak terlihat kotor.

$\checkmark$ Menghindari menyentuh mata, hidung dan mulut.

$\checkmark$ Terapkan etika batuk atau bersin dengan menutup hidung dan mulut dengan lengan atas bagian dalam atau tisu.

$\checkmark$ Menjaga jarak (minimal 1 meter) dari orang yang mengalami gejala gangguan pernapasan.

$\checkmark$ Menguatkan sistem kekebalan diri dengan melakukan perilaku sehat, seperti olah raga teratur serta makan makanan bergizi seimbang.

4) Apa yang perlu dilakukan jika terdapat anggota keluarga yang menunjukkan gejala Virus Corona (COVID-19)?

Sebagian besar masyarakat telah memahami tindakan apa yang harus dilakukan yakni sebagian besar menjawab 
membawa anggota keluarga untuk melakukan pemeriksaan ke pelayanan kesehatan terdekat. Selanjutnya disarankan untuk senantiasa mentaati saran dan anjuran dari tenaga kesehatan.

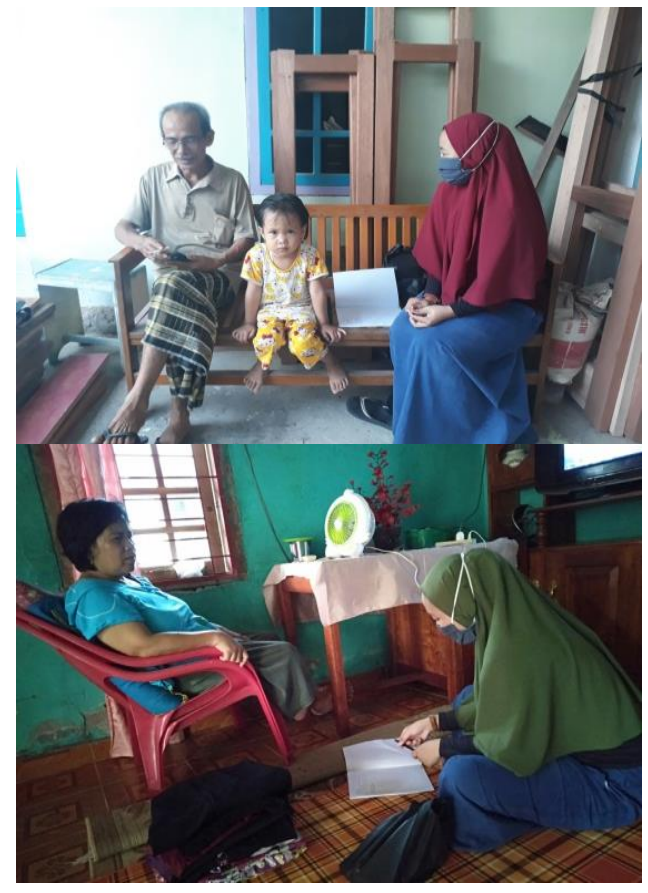

Gambar 1. Edukasi COVID-19

\section{B. Pembagian Brosur}

Brosur merupakan salah satu media untuk dapat menyampaikan informasi. Selain melaksanakan diskusi dan edukasi kepada warga, tim pengabdian kepada masyarakat juga menyediakan brosur yang dikonsep secara sederhana yang berbentuk selembaran kertas yang berisi informasi tentang COVID-19 dan ditambah gambar pendukung.

Brosur memuat ajakan untuk senantiasa berada di rumah atau mengurangi aktivitas di luar rumah. Disampaikan bahwa meski berada di dalam rumah, warga tetap dapat melaksanakan berbagai aktivitas yang memberi kontribusi terhadap perekonomian keluarga. Selanjutnya brosur juga memberi informasi atas gejala yang ditimbulkan dari virus corona. Selain itu, juga menyampaikan upaya pencegahan yang dapat dilakukan.

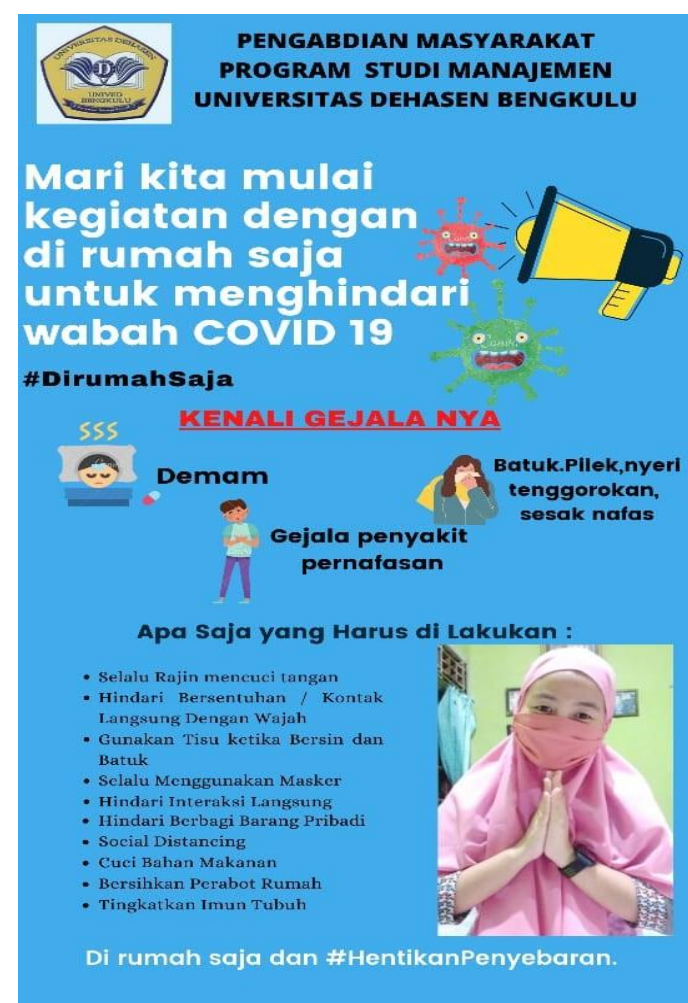

Gambar 2. Brosur Sosialisasi COVID-19

Setelah menyampaikan isi, tujuan dan manfaat brosur kepada warga, selanjutnya tim pengabdian kepada masyarakat meminta izin kepada warga untuk dapat menempel brosur tersebut di bagian rumah warga. Adapun tujuan penempelan atau pemasangan tersebut adalah agar warga senantiasa melihat dan membaca untuk selanjutnya dapat diterapkan. Meski tidak semua warga berkenan untuk dipasang dibagian rumah dengan alasan tertentu, kami senantiasa menghimbau agar warga dapat berupaya mencegah penyebaran virus corona. 


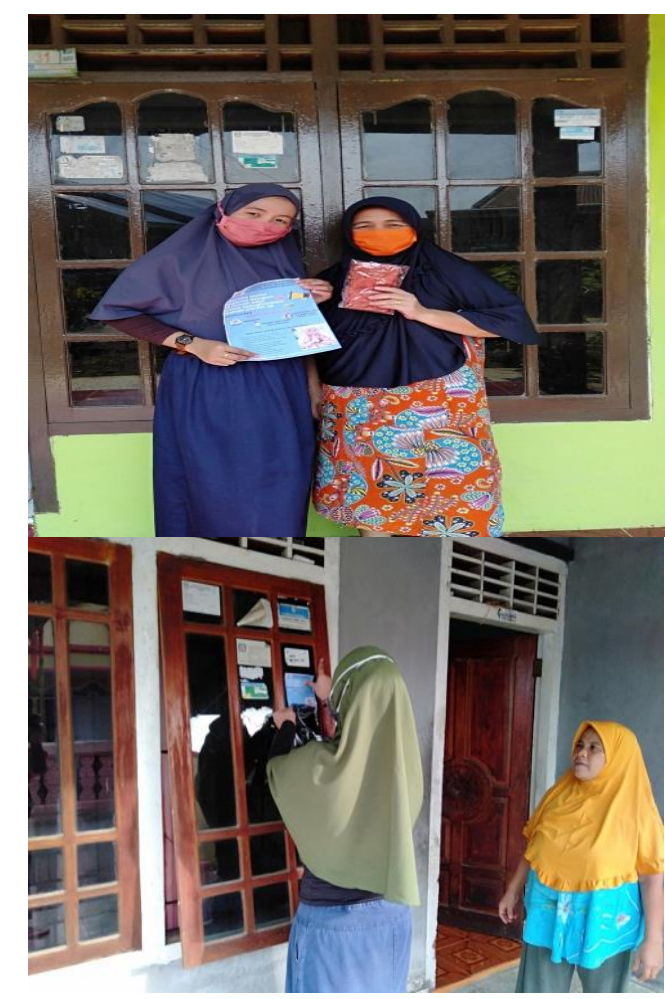

Gambar 3. Penyerahan dan Pemasangan Brosur di Rumah Warga

\section{Pembagian Masker}

Masker diperlukan bagi setiap orang agar tidak saling menulari virus corona. Ada kesempatan tinggi penularan terjadi ketika orang sakit berinteraksi dengan orang sehat dan orang sehat berinteraksi dengan yang lain juga. Penggunaan masker diharuskan juga terkait dengan percikan liur atau droplet.

Adapun jenis masker yang diberikan kepada warga berupa masker kain. Masker kain menjadi alternatif lain yang diperuntukkan bagi masyarakat mengingat masker bedah cenderung langka di pasaran. Bagi masyarakat yang memiliki gejala COVID-19 bisa menggunakan masker kain untuk mencegah droplet maupun partikel yang menjadi airbone agar tidak menularkan ke orang lain. Di samping itu, masker kain bisa dibuat dengan mudah di rumah. Terpenting adalah menggunakan kain yang nyaman dipakai, desainnya bisa dimasuki tisu, dan bisa menahan percikan droplet. Kami juga menyampaikan bahwa masker kain boleh dipakai berulangkali, dengan catatan harus dicuci secara tepat. Mencuci masker kain tidaklah sulit, yakni dengan menggunakan deterjen dan dibasuh dengan air hangat sebagai upaya pencegahan tertular dari virus.

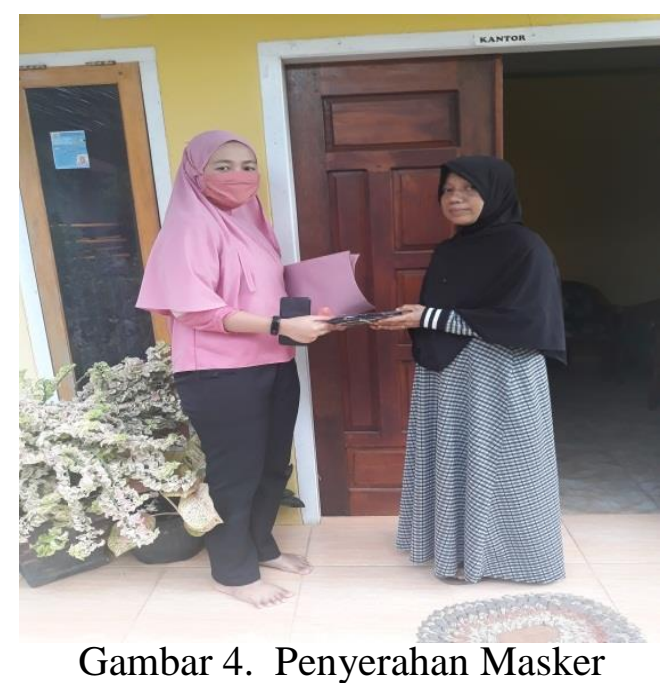

Tema kegiatan pengabdian kepada masyarakat kali ini dianggap sangat sesuai dengan kondisi disaat pandemi COVID-19 masih mewabah. Kegiatan yang dilaksanakan seperti edukasi COVID-19, pemberian brosur dan pemberian masker membantu masyarakat dalam upaya mencegah penyebaran virus corona.

\section{DAMPAK}

Pelaksanaan kegiatan Pengabdian kepada Masyarakat memberikan dampak positif bagi masyarakat yaitu peningkatan pemahaman dan kesadaran masyarakat terhadap bahaya Virus Corona (COVID19) serta terbantunya masyarakat dalam menghadapai dan upaya pencegahan penyebaran virus corona di lingkungannya. Dengan adanya pemahaman terhadap tanda atau gejala inveksi virus, tindakan pencegahan yang dilakukan serta tindakan yang dilakukan jika terdapat anggota keluarga yang menunjukkan gejala Virus Corona (COVID-19). Masyarakat dapat mencegah dan meminimalisir dampak 


\section{Ourratem}

potensi penyebaran virus. Kemudahan masyarakat dalam menerima atau memahami sosialisasi yang dilakukan karena menggunakan media berupa brosur yang diberikan dan dipasang di bagian rumah warga. Metode ini juga dianggap efektif dalam pemahaman dan aplikasi. Selanjutnya, masyarakat terbantu dalam penyediaan masker untuk anggota keluarga. Pemberian masker kain sangat bermanfaat dalam mengurangi potensi penularan virus corona.

\section{PENUTUP}

Kegiatan pengabdian kepada masyarakat yang dilaksanakan selama satu minggu yakni sejak tanggal 15-20 Juni 2020 berjalan dengan lancar. Edukasi COVID-19, membantu warga dalam memahami baik dari pemahaman konsep, tanda atau gejala inveksi virus, tindakan pencegahan yang dilakukan jika terdapat anggota keluarga yang menunjukkan gejala Virus Corona (COVID-19). Melalui brosur yang diberikan dan dipasang di bagian rumah warga juga dianggap efektif dalam pemahaman dan aplikasi. Selanjutnya pemberian masker kain sangat bermanfaat dalam mengurangi potensi penularan virus corona. Seiring dengan pandemi COVID19 yang belum berakhir bahkan masih cenderung mengalami peningkatan kasus, maka kegiatan terkait upaya penanggulangan dampak COVID-19 terutama dalam hal ekonomi keluarga sangat penting untuk dilakukan.

\section{E. DAFTAR PUSTAKA}

Baldwin, Richard., and Mauro, Beatrice Weder di. (2020). Economics in the Time of Covid-19. London. CEPR Press.

Direktorat Jenderal Pencegahan dan Pengendalian Penyakit. (2020). Pedoman Pencegahan dan Pengendalian Coronavirus Disease
(COVID-19). Jakarta. Kementerian Kesehatan Republik Indonesia dan GERMAS.

Gugus Tugas Percepatan Penanganan COVID-19. (2020). Peta Sebaran. https://covid19.go.id/peta-sebaran.

Diakses Tanggal 9 Juli 2020.

Hidayaturrahman, Mohammad dan Purwanto, Edy. (2020). OVID-19: Public Support Against the Government's Efforts to Handle and Economic Challenges. Jurnal Inovasi Ekonomi. Vol. 05 No. 02.

https://mataram.tribunnews.com/2020/07/0

9/update-virus-corona-dunia-9-juli-

2020-121-juta-kasus-500-ribu-

meninggal-pasien-sembuh-meningkat.

Diakses tanggal 9 Juli 2020.

Lupia, Tommaso., Scabini, Silvia., Pinna, Simone Mornese., and Perri, Giovanni Di. (2020). 2019 Novel Coronavirus (2019-nCoV) Outbreak: A New Challenge. Journal of Global Antimicrobial Resistance. 21(2020). 22-27.

Rothan, Hussin A., Byrareddy, Siddappa N. (2020). The Epidemiology and Pathogenesis of Coronavirus Disease (COVID-19) Outbreak. Journal of Autoimmunity.

Shereen, Muhammad Adnan., Khan, Suliman., Kazmi, Abeer., Bashir, Nadia., and Siddique, Rabeea. (2020). COVID-19 Infection: Origin, Transmission, and Characteristics of Human Coronaviruses. Jurnal of Advanced Research. 24(2020), 91-98. 